Gut, 1986, 27, 317-323

Liver and biliary

\title{
In vitro effect of Cyclosporin A on immunoglobulin production and concanavalin A induced suppression in primary biliary cirrhosis
}

\author{
M N A AL-AGHBAR, G J M ALEXANDER, K T NOURI-ARIA, J NEUBERGER, \\ A L W F EDDLESTON, AND ROGER WILLIAMS
}

From The Liver Unit, King's College School of Medicine and Dentistry, Denmark Hill, London and the Liver Unit, Cromwell Hospital, London

SUMmARY The in vitro effect of Cyclosporin A on the regulation of immunoglobulin production was investigated in 16 patients with primary biliary cirrhosis. A significant improvement in concanavalin A induced suppression of IgG and IgM producing cells was observed after prior incubation of mononuclear cells with $300 \mathrm{ng} / \mathrm{ml}$ Cyclosporin A for 30 minutes. No effect was seen on spontaneous or pokeweed mitogen induced immunoglobulin production, nor on con A induced suppression if Cyclosporin A was added after 24 hours. Incubation of mononuclear cells with a variable dose of Cyclosporin A showed an effect only at $250-500 \mathrm{ng} / \mathrm{ml}$. Higher and lower doses had no effect. This dose dependent effect of Cyclosporin $\mathrm{A}$ is likely to be related to a differential inhibitory effect on $\mathrm{T}$ helper and $\mathrm{T}$ suppressor cells and may underlie the clinical benefit being observed in current clinical trials.

Cyclosporin A is being, used with considerable therapeutic success in human organ transplantation $^{12}$ and recently reports have also appeared of its efficacy in conditions that are closely associated with disordered immune responses such as Graves' ophthalmopathy, ${ }^{3}$ corticosteroid resistant posterior uveitis, ${ }^{4}$ diabetes mellitus, ${ }^{5}$ as well as sarcoidosis and Crohn's disease. ${ }^{67}$ The number of cases so far included in many of these studies is small and attention has focused on clinical efficacy rather than the mode of action. The ratio of helper:suppressor/ cytotoxic cells (T4:T8 ratio) has been shown to fall during a pilot study of Cyclosporin $\mathrm{A}$ in primary biliary cirrhosis (PBC) ${ }^{8}$ but functional studies have only rarely been performed in patients.

In primary biliary cirrhosis, hyperglobulinaemia, non-organ specific auto-antibodies and infiltration of the hepatic parenchyma and portal tracts by mononuclear cells suggest abnormalities of cellular and humoral immunity. In a preliminary study, empirical administration of Cyclosporin $A$ was accompanied by improvement in serum biochemistry, but nephrotoxicity was common and the trial was stopped. ${ }^{8}$ Recently we have found it possible to use Cyclosporin A at lower doses, with a reduction in

Address for correspondence: Dr Roger Williams FRCP, Liver Unit, Kings College Hospital School of Medicine, Denmark Hill, London SE5 8RX. Received for publication 24 June 1985. symptoms and without nephrotoxicity. ${ }^{9}$ The purpose of the present study was to investigate the effect of Cyclosporin A on immunoglobulin production and its regulation, as defective suppression of immunoglobulin production has been observed in primary biliary cirrhosis, ${ }^{1011}$ particularly in those with early disease (personal observation).

\section{Methods}

\section{PATIENTS}

The 16 patients (median age 48.6 years, range 53-73 years) investigated, including one man, had histologically proven primary biliary cirrhosis. Five had early disease as assessed histologically (stage II) and 11 late disease (stage III or IV). ${ }^{12}$ Three patients were antimitochondrial antibody positive in a titre of less than 1/20. None of the patients was on treatment at the time of the study (Table 1). Six laboratory personnel, all men (median age 28 years, range 26-30 years) served as healthy controls. Previous studies have demonstrated that suppressor cell function is not related to sex or age ${ }^{13}$ and this has been confirmed for suppressor cell function in this laboratory for sex and age up to 70 years. ${ }^{14}$

CELL SEPARATION

Venous blood mixed with dextran $(6 \% \mathrm{w} / \mathrm{v})$ in 
Table 1 Relevant clinical data of the 16 patients with primary biliary cirrhosis (values are given as ranges)

\begin{tabular}{llllllll}
\hline & Women/men & Age & $\begin{array}{l}\text { Bilirubin molll } \\
\text { (normal } \\
<17 \mu m o l l l)\end{array}$ & $\begin{array}{l}\text { Serum } \\
\text { aminotransferase } \\
\text { (normal }<45 \mu m / l)\end{array}$ & $\begin{array}{l}\text { Antimito- } \\
\text { chondrial } \\
\text { antibody } \\
>1 / 20\end{array}$ & IgG $g / l$ & IgM $g / l$ \\
\hline $\begin{array}{l}\text { Early disease } \\
\text { (Stage II) }\end{array}$ & $5 / 0$ & $43-66$ & $15-49$ & $40-144$ & 3 & $6 \cdot 4-22 \cdot 6$ & $3 \cdot 8-13 \cdot 0$ \\
$\begin{array}{l}\text { Late disease } \\
\text { (Stage III or IV) }\end{array}$ & $10 / 1$ & $44-47$ & $15-81$ & $24-426$ & 10 & $9 \cdot 8-18 \cdot 9$ & $1 \cdot 6-8 \cdot 9$ \\
\hline
\end{tabular}

$0 \cdot 15 \mathrm{~mol} \mathrm{NaCl}$ and heparin $(10 \mathrm{U} / \mathrm{ml})$, was suspended at $37^{\circ} \mathrm{C}$ for 45 minutes to allow sedimentation of red cells. Leucocyte rich plasma was centrifuged on Ficoll-Triosil at $400 \mathrm{~g}$ for 20 minutes and the mononuclear cells then depleted of monocytes by incubation in plastic Petri dishes for 45 minutes at $37^{\circ} \mathrm{C}$. The non-adherent cells were then washed three times in Hanks balanced salt solution and resuspended at $10^{6}$ cells $/ \mathrm{ml}$ in $20 \%$ heat inactivated fetal calf serum in RPMI 1640 (Gibco) containing $2 \mathrm{mM}$ glutamine, $200 \mu$ penicillin $/ \mathrm{ml}, 100 \mu \mathrm{g}$ strepto$\mathrm{mycin} / \mathrm{ml}$ and $2 \mu \mathrm{g}$ amphotericin $\mathrm{B} / \mathrm{ml}$. Peroxidase activity was $3-5 \%$.

\section{CELL CULTURE}

$2 \times 10^{5}$ cells peripheral blood mononuclear cells at $10^{6} \mathrm{cells} / \mathrm{ml}$ were cultured in flat-bottomed microplates (Sterilin) in the presence or absence of pokeweed mitogen (Sigma) $20 \mu \mathrm{g} / \mathrm{ml}$. Simultaneously, peripheral blood mononuclear cells at $2 \times 10^{5} \mathrm{cells} / \mathrm{ml}$ were incubated with concanavalin-A $20 \mu \mathrm{g} / \mathrm{ml}$ for 24 hours and then washed three times in Hanks balanced salt solution (HBSS) containing 0.3 M $\alpha$-methyl-D-mannoside to remove concanavalin A. After further washes in HBSS, these cells were resuspended in $20 \%$ fetal calf serum in RPMI 1640 at $10^{6}$ cells $/ \mathrm{ml}$. Equal numbers of concanavalin A stimulated and unstimulated peripheral blood mononuclear cells were then cultured with pokeweed mitogen at $20 \mu \mathrm{g} / \mathrm{ml}$ as outlined above (viability, assessed by Trypan Blue exclusion, exceeded $93 \%$ after culture with concanavalin A).

HAEMOLYTIC PLAQUE ASSAY

After seven days, peripheral blood mononuclear cells were harvested by centrifugation, washed three times in RPMI 1640 and resuspended at $10^{5} \mathrm{cells} / \mathrm{ml}$. Viability ranged from $66-96 \%$. Fifty microlitres peripheral blood mononuclear cells was mixed with $50 \mu \mathrm{l} 10 \%$ sheep red blood cells coated with staphylococcal protein A (Pharmacia), $50 \mu \mathrm{l}$ of an appropriately diluted IgG fraction of rabbit antihuman IgG (or IgM) and $700 \mu \mathrm{l}$ agarose Indubiose (Reactifs IBF) and poured into plastic Petri dishes and incubated for four hours at $37^{\circ} \mathrm{C}$. After developing with guinea pig complement for $\mathbf{2}$ hours, haemolytic plaques were counted visually in indirect light and the results expressed as the number of IgG (or IgM) producing cells per $10^{6}$ viable peripheral blood mononuclear cells. Proliferation of immunoglobulin producing cells has been assessed in the absence of any mitogens to determine the number of cells spontaneously producing immunoglobulin and in the presence of pokeweed mitogen alone. Concanavalin $\mathrm{A}$ induced suppression is defined as:

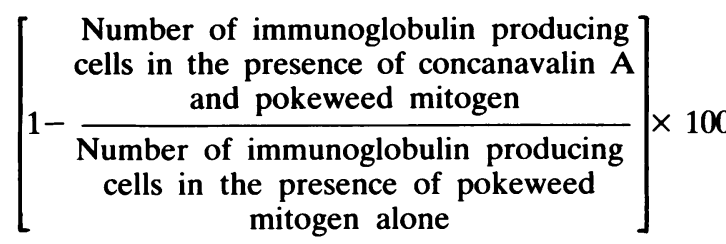

To assess the effect of Cyclosporin A, peripheral blood mononuclear cells were incubated with Cyclosporin A (dissolved in $100 \%$ ethanol and then RPMI 1640 to give a final concentration of $300 \mathrm{ng} / \mathrm{ml}$ in $0 \cdot 15 \%$ ethanol) for $30^{\prime}$ at $37^{\circ}$. After incubation, peripheral blood mononuclear cells were washed in HBSS three times and suspended in RPMI containing $20 \%$ heat inactivated fetal calf serum. Mean viability, by Trypan blue exclusion was $98 \%$. As a control, Cyclosporin A solvent (courtesy Sandoz) was dissolved in identical concentrations of ethanol and RPMI 1640. Peripheral blood mononuclear cells from patients and controls were incubated in Cyclosporin A or control media at one of four stages, namely (1) prior to unstimulated culture; (2) prior to culture with pokeweed mitogen; (3) prior to culture with concanavalin A; and (4) after $24 \mathrm{~h}$ culture with concanavalin A. Subsequently varying doses of Cyclosporin A were used prior to culture with concanavalin A.

\section{STATISTICS}

For immunoglobulin production, the data are presented as medians (range), while for suppression, the data are presented as means ( \pm 1 SD). Comparison has been made using the paired Rank test. 
Table 2 Effect of preincubation of peripheral blood mononuclear cells with Cyclosporin A on in vitro immunoglobulin production in primary biliary cirrhosis and normal controls (values expressed as median number of cells (range)/10 peripheral blood mononuclear cells producing IgG or IgM)

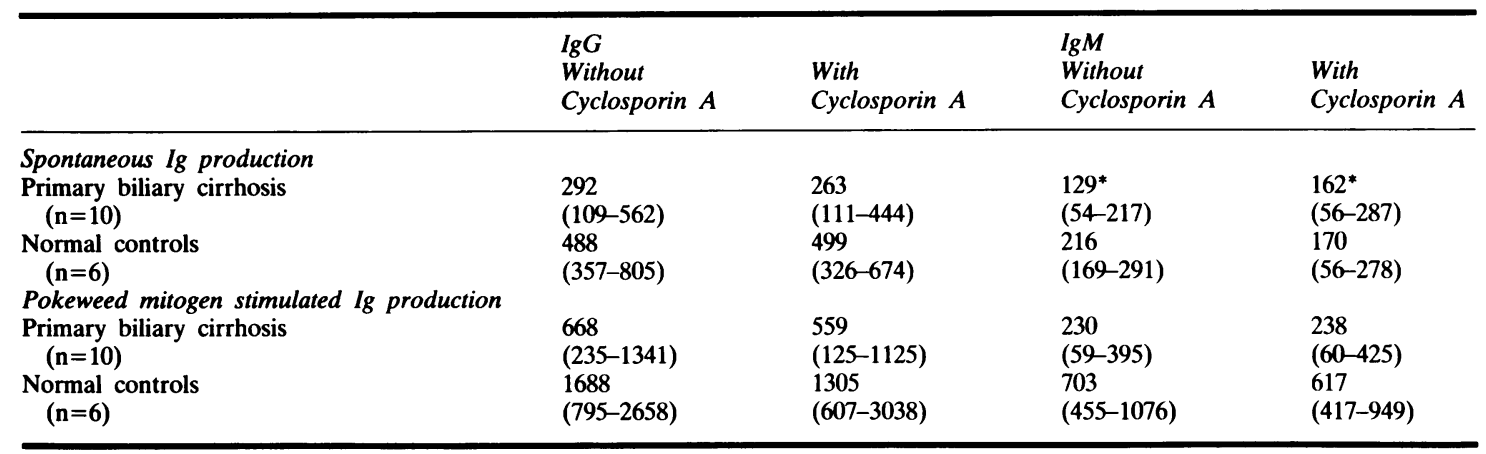

${ }^{*} \mathrm{p}=0.05$

\section{Results}

In the absence of mitogen, the number of lymphocytes from patients with primary biliary cirrhosis producing IgG was unaffected by preincubation with Cyclosporin A although the number of lymphocytes producing IgM was slightly higher after incubation with Cyclosporin $A(p=0 \cdot 05)$. When pokeweed mitogen was added, the number of cells producing IgG or IgM was unaffected by incubation with Cyclosporin A (Table 2). Similarly the number of cells from normal controls producing IgG or IgM, spontaneously or after the addition of pokeweed mitogen, was unaffected by incubation with Cyclosporin A.
SUPPRESSOR CELL FUNCTION

Preincubation of peripheral blood mononuclear cells with Cyclosporin A, before activation with concanavalin A, had a marked effect on the suppression of both IgG and IgM producing cells from 10 patients with primary biliary cirrhosis. Per cent suppression of IgG producing cells rose from $35 \cdot 7 \pm 14.0$ to $73 \cdot 7 \pm 12 \cdot 0$ (mean $\pm 1 \mathrm{SD}, \mathrm{p}<0.01$, Figure 1) while that for IgM producing cells rose from $46 \cdot 0 \pm 13 \cdot 0$ to $76 \cdot 0 \pm 8 \cdot 0$ ( $p<0.01$, Figure 1). In contrast, preincubation of peripheral blood mononuclear cells with Cyclosporin A, before activation with concanavalin A, had no effect on suppression of IgG or IgM producing cells from 6 normal controls (mean \% suppression \pm 1 SD with and without Cyclosporin $A$ 71.0 17.0 and

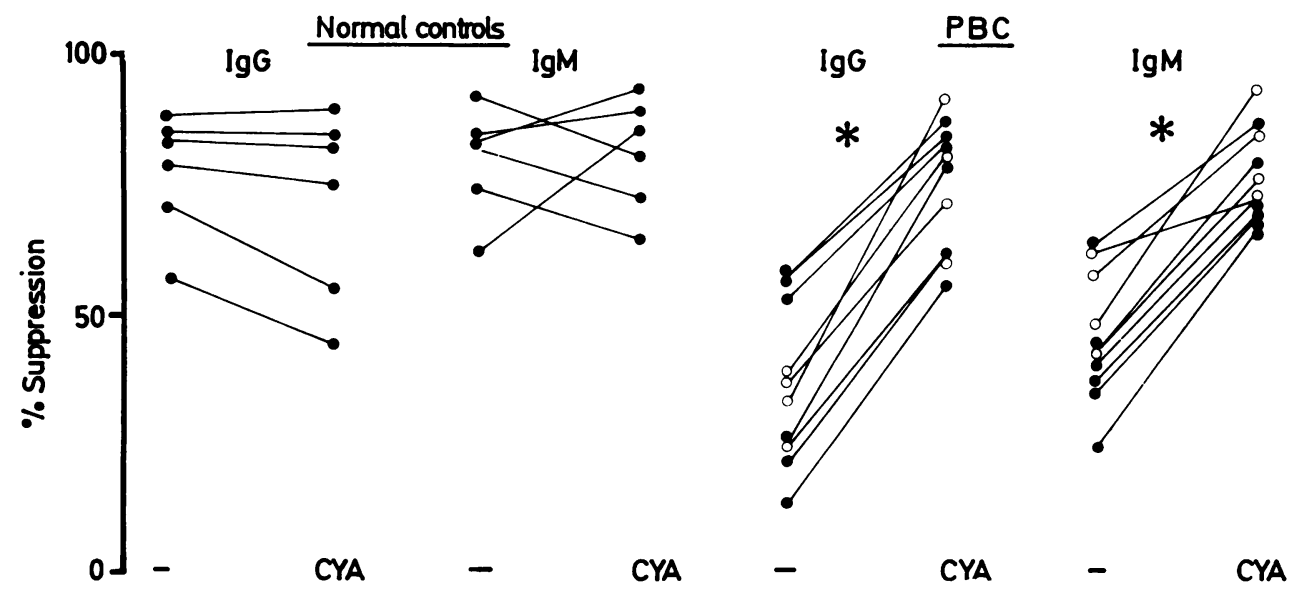

Fig. 1 Effect of incubation peripheral blood mononuclear cells with Cyclosporin A, before concanavalin A activation, on suppressor cell regulation of the number of $\mathrm{IgG}$ or IgM producing cells in normal controls and primary biliary cirrhosis. For those with primary biliary cirrhosis closed circles represent those with stage III or IV disease, open circles those with stage I or II disease $\left({ }^{*} p<0.01\right)$. 


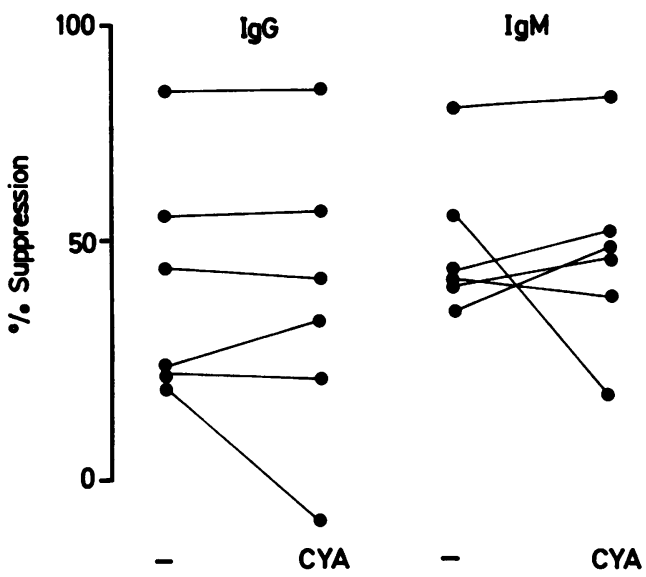

Fig. 2 Effect of incubation of peripheral blood mononuclear cells with Cyclosporin A, after activation with concanavalin $A$, on suppressor cell regulation of the number of IgG or IgM producing cells in primary biliary cirrhosis.

$77 \cdot 0 \pm 11.0$ respectively for $\operatorname{IgG}$ and $81.0 \pm 9 \cdot 0$ and $79 \cdot 0 \pm 10 \cdot 0$ respectively for IgM, $p=N S$ ).

To determine whether the timing of exposure of peripheral blood mononuclear cells to Cyclosporin A was important, suppression was measured in patients with primary biliary cirrhosis with Cyclosporin A being added after peripheral blood mononuclear cells had been cultured with concanavalin A, but before the addition of pokeweed mitogen. No effect was seen on the suppression of IgG or IgM producing cells (mean $\% \pm 1$ SD, $42.2 \pm 22.0$ and $41.0 \pm 28.0$ for IgG and $51.0 \pm 13.0$ and $50.0 \pm 18.0$ for IgM in the absence or presence of Cyclosporin A respectively,
$p=N S$, Fig. 2). To exclude an effect of the Cyclosporin A solvent, suppression was also measured with or without preincubation with the solvent, before exposure to concanavalin $\mathrm{A}$ in those with primary biliary cirrhosis. No effect on suppression was seen for either IgG (mean \% \pm 1 SD, 37.0 \pm 14.0 and $40.6 \pm 17.0$ in the absence or presence of Cyclosporin A solvent respectively, $\mathrm{p}=\mathrm{NS}$ ) or IgM (46.0 \pm 13.0 and $42.0 \pm 20.0$ in the absence or presence of Cyclosporin A solvent respectively, $p=N S$ ).

\section{EFFECT OF VARIED CONCENTRATIONS OF CYCLOSPORIN A ON CONCANAVALIN A IN DU CED S UPPRESSION}

The effect of preincubation with varied concentrations of Cyclosporin A, before concanavalin A activation, on suppression was further investigated in six of the patients with a defect of IgG suppression. The concentrations were $0,50,100,250,500$, 750 , and $1000 \mathrm{ng} / \mathrm{ml}$. Insufficient lymphocytes were obtained from any individual to assess the effect at every concentration simultaneously, so that each was studied at alternate concentrations. Viability was unaffected at any concentration (at 50 and $100 \mathrm{ng} / \mathrm{ml}$ mean viability $98 \%$, at $250 \mathrm{ng} / \mathrm{ml} 97 \%$, at $500 \mathrm{ng} / \mathrm{ml} 96 \%$, and at $1000 \mathrm{ng} / \mathrm{ml} 98 \%$ ). No effect was seen on suppression of either IgG or IgM producing cells at 50 or $100 \mathrm{ng} / \mathrm{ml}$ Cyclosporin $\mathrm{A}$, while the maximum effect on suppression was observed at $250 \mathrm{ng} / \mathrm{ml}$, declining at higher concentrations (Fig. 3).

\section{Discussion}

The results of this study show that Cyclosporin $\mathrm{A}$ has a highly selective action on peripheral blood mono-

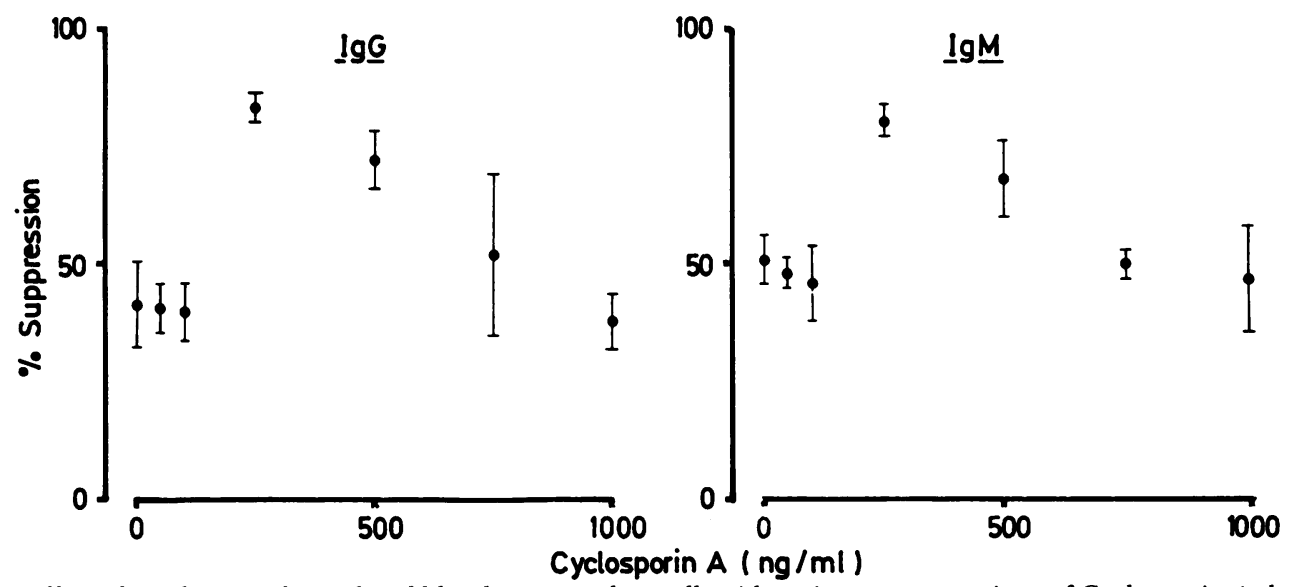

Fig. 3 Effect of incubation of peripheral blood mononuclear cells with various concentrations of Cyclosporin A, before concanavalin A activation, on suppressor cell regulation of the number of IgG or IgM producing cells in primary biliary cirrhosis (see text). Values are given as the mean \pm 1 SD. 
nuclear cells from patients with primary biliary cirrhosis and that this is confined to concanavalin A induced suppression of immunoglobulin production while spontaneous and pokeweed mitogen stimulated immunoglobulin production were unaffected. The defect of concanavalin $\mathrm{A}$ induced suppression is independent of the stage and severity of hepatic inflammation ${ }^{10}$ and a similar defect has been identified in healthy first degree relations of patients with primary biliary cirrhosis. ${ }^{12}$ Although a precise role for such a defect in the aetiology of primary biliary cirrhosis has not been defined, correction of the defect in vitro by Cyclosporin $\mathrm{A}$ is intriguing. Suppression, as measured in this study, however, is a balance between helper and suppressor cell function and the effect of Cyclosporin A may be due to a direct inhibitory action on B cells or be mediated by inhibition of concanavalin $A$ activated $T$ helper cells or stimulation of concanavalin A activated suppressor cells.

Although initial studies had suggested that B lymphocytes were resistant to Cyclosporin $A^{1516}$ more recent studies in man and animals have indicated that certain $\mathrm{B}$ cells are sensitive. ${ }^{17}$ In the mouse a proportion of $B$ cells responsive to $T$ independent antigens (T-I2) are Cyclosporin A sensitive $^{18}$ while in man Cyclosporin A modulates the $T$ independent $B$ cell response to anti- $\mu$ and Staphylococcus aureus Cowan. ${ }^{19}$ The action of Cyclosporin A may be mediated by inhibition of induction of functionally active B cell growth factor receptors, essential for the proliferation of activated $\mathrm{B}$ cells. ${ }^{20}$ Inhibition of B cells, however, is unlikely to underlie increased suppression seen in the present study as no effect was observed in either spontaneous or pokeweed mitogen stimulated culture. The lack of effect of Cyclosporin A in these cultures suggests that the cells are already fully activated, presumably a consequence of in vivo activation, and that they have already differentiated beyond the stage of activation that is sensitive to Cyclosporin A.

Cyclosporin A inhibits the response to several mitogens although concanavalin $\mathrm{A}$ is the lectin most sensitive to its action, ${ }^{21} 22$ and concanavalin A activated $T$ cells were the most likely target for Cyclosporin A in the present study. Previous studies have shown that Cyclosporin A can inhibit $\mathrm{T}$ helper cells $^{23}$ while a stimulatory effect on $\mathrm{T}$ suppressor cells is less likely. In the mixed leucocyte reaction, Cyclosporin A has been shown to inhibit cytotoxic cells selectively with much less effect on suppressor cells at the same dose. ${ }^{21}{ }^{24}$ Similarly, in a murine model of autoimmune haemolytic anaemia, Cyclosporin A appeared to allow the expression of suppressor cells regulating the production of autoantibody to murine red cells, but not those regulat- ing antibody production to rat erythrocytes, the priming antigen. ${ }^{25}$ Thus Cyclosporin A exerts a dose dependent differential effect on various limbs of the immune system.

Several studies have suggested that the inhibitory effects of Cyclosporin A are probably directed against the earliest stages of activation. The precise level of inhibition remains to be elucidated, but Cyclosporin A allows expression of the Tac receptor, while inhibiting secretion of IL-1 and IL-2 and inhibiting expression of T9, T10 and DR antigens. ${ }^{26-30}$ These observations may be related to inhibition of protein synthesis by unstimulated lymphocytes. ${ }^{30} 31$ If, however, activation has already occurred, then Cyclosporin A exerts no effect, which explains why in this study Cyclosporin A was effective only before exposure to concanavalin A.

In this context, the observation that suppression is augmented at a concentration of $250 \mathrm{ng} / \mathrm{ml}$ but unaffected or inhibited at concentrations of $>500 \mathrm{ng} / \mathrm{ml}$ is of interest. A possible explanation may be that Cyclosporin A exerts an inhibitory effect on $\mathrm{T}$ helper and $\mathrm{T}$ suppressor cells but that $\mathrm{T}$ suppressor cells are relatively resistant at lower concentrations - a further example, of the dose dependent differential effect previously observed.

A differential effect on the function of lymphocytes is consistent with the characteristics of uptake of Cyclosporin A by various mononuclear cells. There is no evidence of a specific receptor for Cyclosporin $\mathrm{A}$ on lymphocytes but binding characteristics are distinctive. B lymphocytes have both high and low affinity binding sites, while T lymphocytes have only low affinity binding sites and $T$ helper cells bind Cyclosporin A more avidly than $\mathrm{T}$ suppressor cells, and binding is complete within 2-15 minutes. ${ }^{32}$ The concentration used in the first part of this study is within the recommended range for trough plasma concentrations for patients undergoing organ transplantation. The concentrations at which suppressor cell function was unaffected or inhibited in the present study, $500-1000 \mathrm{ng} / \mathrm{ml}$, are similar, however, to peak concentrations achieved in such patients.

We have previously shown that Cyclosporin A, at doses of $2-4 \mathrm{mg} / \mathrm{kg}$, also corrects suppressor cell function in vivo in patients with primary biliary cirrhosis. ${ }^{33}$ The clinical usefulness of Cyclosporin A in primary biliary cirrhosis may, however, be limited by its lack of effect on spontaneous immunoglobulin production as well as the narrow range of concentrations over which it inhibits suppressor cell function. Interestingly, the range of activity of Cyclosporin $\mathrm{A}$ in vitro in primary biliary cirrhosis was identical to that previously described for prednisolone in primary biliary cirrhosis, ${ }^{10}$ while a 
number of uncontrolled reports have documented improvement in liver function tests after administration of corticosteroids. ${ }^{893435}$

The support of Sandoz Ltd. towards clinical studies of Cyclosporin is gratefully acknowledged. JN is a Welcome Senior Clinical Research Fellow.

\section{References}

1 Calne RY, Rolles K, White DJG et al. Cyclosporin A initially as the only immunosuppressant in 34 recipients of cadaveric organs: 32 kidneys, 2 pancreases and 2 livers. Lancet 1979; 2: 1033-6.

2 Starzl TE, Iwatsuki G, Klintmalm G, Schröter J, Weil R, Koep LJ, Porter KA. Liver transplantation 1980, with particular reference to Cyclosporin A. Transplant Proc 1981; 13: 281-5.

3 Weetman AP, Macgregor AM, Ludgate M, Beck L, Mills PV, Lazarus JH, Hall R. Cyclosporin improves Graves' ophthalmolopathy. Lancet 1983; 2: 486-9.

4 Nussenblatt RB, Palestine AG, Rook AH, Scher I, Wacker WB, Gery I. Treatment of intraocular inflammatory disease with cyclosporin A. Lancet 1983; 2: 235-8.

5 Stiller C, Dupre J, Gent M, Jenner MR, Keown PA, Laupacis A, Martell R, Rodger NW, von Graffenried $B$, Wolfe BM. Effects of cyclosporin in recent onset insulin dependent diabetes mellitus. Science 1984; 223: 1362-7.

6 Rebuck AS, Stiller CR, Braude AC, Laupacis A, Cohen RD, Chapman KR. Cyclosporin for pulmonary sarcoidosis. Lancet 1984; 1: 1174.

7 Allison MC, Pounder RE. Cyclosporin for Crohn's disease. Lancet 1984; 1: 902-3.

8 Routhier G, Epstein O, Janossy G, Thomas HC, Sherlock S. Effects of cyclosporin A on suppressor and inducer $\mathbf{T}$ lymphocytes in primary biliary cirrhosis. Lancet 1981; 2: 1223-6.

9 Alexander GJM, Al-Aghbar MNA, Neuberger J, Nouri-Aria KT, Neuberger J, Eddleston ALWF, Williams R. Correction of the suppressor cell defect of PBC by Cyclosporin A. [Abstract]. Liver 1984; 4: 74.

10 James SP, Elson CO, Jones EA, Strober W. Abnormal regulation of immunoglobulin synthesis in vitro in primary biliary cirrhosis. Gastroenterology 1980; 79: 242-54.

11 Miller KB, Sepersky RA, Brown KM, Goldberg MJ, Kaplan MM. Genetic abnormalities of immunoregulation in primary biliary cirrhosis. Am J Med 1983; 75: 75-80.

12 De Groote J, Desmet VJ, Gedigk P, Korb G, Popper H, Poulsen H, Scheur P, Schmid M, Thaler H, Uehlinger E, Wepler N. A classification of chronic hepatitis: Lancet 1968; 2: 626-9.

13 Hallgren HM, Kersey JH, Dubey DP, Yunis ES. Lymphocyte subsets and integrated immune function in ageing humans. Clin Immunol Immunopathol 1978; 10: 65-78.

14 Nouri-Aria KT, Donaldson PT, Hegarty JE, Eddleston
ALWF, Williams R. HLA A1-B8-DR3 and suppressor cell function in first degree relatives of patients with autoimmune chronic active hepatitis. J Hepatol 1985; 1: 235-41.

15 Borel JF, Feurer C, Magnee C, Staehelin H. Effects of the new anti-lympocyte peptide Cyclosporin $A$ in animals. Immunology 1977; 32: 1017-25.

16 White DJG, Plumb AM, Parvelec G, Brons G. Cyclosporin A: an immunosuppressive agent preferentially active against proliferating $\mathrm{T}$ cells. Transplantation 1979; 27: 55a.

17 Paavonen G, Järvelelämen H, Kontiainen S, Häyry P. Effect of cyclosporin A on in vitro proliferative activity and immunoglobulin $A$ on in vitro proliferative human lymphoid cell subpopulation. Clin Exp Immunol 1981; 43: 432-50.

18 Kunkl A, Klaus GGB. Selective effects of Cyclosporin $A$ on functional B cell subset in the mouse. J Immunol 1980; 125: 2526-31.

19 Muragachi A, Butler JL, Kerhl JH, Falkoff RJM, Fauci AS. Selective suppression of an early step in human B cell activation by Cyclosporin A. J Exp Med 1983; 158: 690-702.

20 Muragachi A, Kehrl JH, Butler JL, Fauci AS. Sequential requirements for cell cycle progression of resting human B cells following activation by anti-Ig. J Immunol 1984; 132: 176-80.

21 Hess AD, Tutschka PJ. Effect of cyclosporin A on human lymphocyte responses in vitro. J Immunol 1980; 124: 2601-8.

22 Hess AD, Matyas JR, Tutschka PJ. Inhibition of in vitro human lymphocyte responses by cyclosporin $\mathbf{A}$. Exp Hematol 1979; 7: 104-9.

23 Borel JF, Wiesinger EH, Collins KH, Hutchinson IF, Tilncy NL, Mannick JA. Suppressive effects in vitro and in vivo. J Immunol 1981; 127: 89-93.

25 Cox KO, Allison AC, Samcewicz B. Experimental erythrocyte auto-immunity prevented by suppressor $\mathrm{T}$ cells in mice treated with Cyclosporin A. Clin Immunol Immunopathol 1983; 28: 90-95.

26 Larsson EL. Cyclosporin A and dexamethasone suppress $\mathrm{T}$ cell responses by selectively acting at distinct sites of the triggering process. J Immunol 1980; 124: 2828-33.

27 Bunjes D, Hardt C, Rollinghoff $\mathbf{M}$, Wagner $\mathbf{H}$. Cyclosporin A mediates immunosuppression of primary cytotoxic $\mathrm{T}$ cell responses by impairing the release of interleukin 2. Europ J Immunol 1981; 11: 657-61.

28 Palacios R, Möller G. Cyclosporin A blocks the receptors for HLA-DR antigens in T cells. Nature (Lond) 1981; 209: 792-4.

29 Miyawaki T, Yachie A, Ohzeki S, Nagaoki T, Taniguchi N. Cyclosporin A does not prevent expression of Tac antigen, a probable TCGF receptor molecule, on mitogen stimulated $\mathrm{T}$ cells. J Immunol 1983; 130: 2737-42.

30 Leoni P, Garcia RC, Allison AC. Effects of cyclosporin A on human lymphocytes in culture. J Clin Lab Immunol 1978; 1: 67-72.

31 Kay JE, Benzie CR. Effects of cyclosporin A on the metabolism of unstimulated and mitogen-activated lymphocytes. Immunology 1983; 49: 153-60. 
32 Kahan BD, Kerman RH, Agostino G, Friedkman A. Legrue SJ. The action of cyclosporin $A$ on human lymphocytes. In: ed. White DG Cyclosporin $A$. Amsterdam: Elsevier, 1982: 281.

33 Al-Aghbar MNA, Alexander GJM, Neuberger J, Nouri-Aria KT, Eddelston ALWF, Williams R. Effects of Cyclosporin A on suppressor cell function in vito and in vitro in primary biliary cirrhosis. [Abstract] Gut
1983; 24: A970.

34 Carman CT, Giansiracusa JE. Effect of steroid therapy on the clinical and laboratory features of primary biliary cirrhosis. Gastroenterology 1955; 28: 193-215.

35 Howat HT, Ralston AS, Varley H, Wilson JAC. The late results of a long-term treatment of primary biliary cirrhosis with corticosteroids. Rev Int Hepatol 1966; 16: 227-38. 